\title{
Efektivitas Belajar Al-Qur'an Dengan menggunakan Aplikasi Hijaiyah Berbasis Budaya Lokal “Nggahi Mbojo" (Bahasa Bima) Pada Lansia di Kabupaten Dompu
}

\author{
Arifin', Fathirma'ruf', Ilyas Yasin ${ }^{3}$ \\ 1,2 Dosen Program Studi Pendidikan Teknologi Informasi, STKIP Yapis Dompu \\ ${ }^{3}$ Dosen Program Studi Pendidikan Sejarah, STKIP Yapis Dompu \\ E-mail: $\underline{\text { arifinku1212@gmail.com }}$
}

Article History: Received: 2020-09-14 || Revised: 2020-10-02 || Published: 2020-10-26

Sejarah Artikel : Diterima: 2020-09-14 || Direvisi: 2020-10-02 || Dipublikasi: 2020-10-26

\begin{abstract}
This study aims to measure the ability to learn Al-Quran in the elderly after being given the application of hijaiyah letters as a learning medium to recognize and memorize the letters of the Al-Quran. This research was conducted in August 2020, the research sample came from the Tembalae Elderly Group, Ranggo Village, Dompu Regency, totaling 30 students with the age category of elderly students. This type of research is a preexperimental design using the type of One-Shoot Case Study (One Shot Case Study). The data collection technique used was a test. The test in question is a test of students' ability to read al-Quran with indicators of fluency, accuracy of makhra, accuracy of tajwid and tanwin. To determine the level of ability to read the AlQuran students were then analyzed descriptively quantitatively. The training process, guidance to the test were carried out 8 times face to face with students divided into six study groups. Based on the findings of data analysis and discussion, it can be concluded that the use of hijaiyah application based on local culture "Nggahi Mbojo" (Bima Language) is very effective as a support for the learning process to read the Al-Quran.for the elderly in Dompu Regency. This result is evidenced by the results of the test results of the ability to read the Al-Quran 30 students (elderly) obtained an average of $80 \%$ in the good category. These results are also supported by internal factors, namely the motivation and enthusiasm of students in using the application developed as a medium for learning to read the Al-Quran.
\end{abstract}

Keywords: Effectiveness, Al-Quran, local culture, Nggahi mbojo

\begin{abstract}
Abstrak
Penelitian ini bertujuan untuk mengukur kemampuan belajar Al-quran lansia setelah diberikan aplikasi huruf hijaiyah sebagai media pembelajaran mengenal dan menghafal huruf al-quran. Penelitian ini dilakukan pada bulan Agustus 2020, sampel penelitian berasal dari Kelompok Lansia Tembalae Desa Ranggo Kabupaten Dompu berjumlah 30 orang peserta didik dengan kategori usia peserta didik lanjut usia (lansia). Jenis penelitian ini adalah pre-experimental design menggunakan tipe One-Shoot Case Study (Studi Kasus Satu Tembakan). Teknik pengumpulan data yang digunakan adalah tes. Tes yang dimaksud adalah tes kemampuan baca al-quran peserta didik dengan ukuran indikator kelancaran, ketepatan makhra, ketepatan tajwid dan tanwin. Untuk mengetahui tingkat kemampuan baca al-quran peserta didik kemudian dianalisis secara deskriptif kuantitatif. Proses pelatihan, bimbingan sampai denga tes dilakukan 8 kali tatap muka dengan peserta didik dibagi dalam enam kelompok belajar. Berdasarkan hasil temuan analisis data dan pembahasan bahwa dapat disimpulkan penggunaan aplikasi hijaiyah berbasis budaya lokal "Nggahi Mbojo" (Bahasa Bima) sangat efektif sebagai penunjang proses pembelajaran baca al-quran pada Lansia Kabupaten Dompu. Hasil ini dibuktikan dengan hasil tes kemampuan baca al-quran 30 orang peserta didik (lansia) memperoleh rerata $80 \%$ dengan kategori baik. Hasil ini didukung juga faktor internal yaitu motivasi dan semangat peserta didik dalam mennggunakan aplikasi yang dikembangkan sebagai media pembelajaran baca Al-Quran.
\end{abstract}

Kata kunci: Efektivitas, Al-Quran, Budaya lokal, Nggahi mbojo.

\section{PENDAHULUAN}

Pendidikan agama adalah pendidikan yang penting bagi setiap individu. Pendidikan agama dibutuhkan oleh setiap individu dalam berbagai usia, mulai dari anak-anak, remaja, orangtua hingga lansia. Hal ini dikarenakan ilmu agama adalah ilmu yang harus dipraktekan dalam 
keseharian, mulai dari aspek aqidah, akhlak, dan juga ibadah. Ibadah praktis yang pokok dilakukan oleh seorang muslim adalah mengerjakan sholat dan membaca Al-Qur'an. Sholat a dalah upaya seorang muslim mendekatkan diri kepada Allah, sedangkan membaca Al-Qur'an adalah upaya dasar untuk memahami hukum-hukum Allah yang terdapat dalam Al-Qur'an (Manna. 2017) Pentinya belajar Al-quran merupakan amanah yang ditekankan oleh Nabi Muhammad SAW., hal ini sebagaimana sabda hadist Rasulullah SAW yaitu, "Orang yang tidak mempunyai hafalan Alquran sedikitpun seperti rumah kumuh yang mau runtuh". (HR at-Tirmizi). Tak cuma itu, Nabi Muhammad SAW pun menghormati orang-orang yang mempunyai keahlian dalam membaca Alquran dan menghafalnya, memberitahukan kedudukan mereka serta mengedepankan mereka dibandingkan orang lain.

Hadist di atas dapat dimaknai bahwa setiap muslim tidak dibatasi usia, jenis kelamin latar maupun belakang pendidikan untuk dianjurkan membaca Al-qur'an. Begitu pula keberadaan warga lanjut usia (lansia) di Desa Ranggo Kabupaten Dompu sangat perlu ditingkatkan kemampuan baca Al-Qur'annya. Hal ini didasarkan hasil pendataan peneliti pada Bimas Islam Kementrian Agama Kabupaten Dompu dan Penyuluh Agama Islam Non PNS bahwa masih banyak lansia yang belum mengenal huruf hijaiyah dan salah satunya lansia yang berada di Desa Ranggo Kec. Pajo Kabupaten Dompu. Seiring berkembangnya ilmu pengetahuan dan teknologi saat ini, pendidikan merupakan sasaran utama dalam implementasi berbagai macam teknologi yang dikembangkan. Tidak heran saat-saat ini berbagai aplikasi bermunculan dengan peran sebagai media pembelajaran alternatif dan solusi dalam menuntaskan hasil belajar peserta didik. Media pembelajaran adalah komponen yang sangat vital dalam proses pembelajaran, karena media pembelajaran menjadi salah satu faktor penentu berhasil atau tidaknya suatu nilai tersampaikan pada siswa. Media memberikan kontribusi positif dalam suatu proses pembelajaran. Pembelajaran yang menggunakan media yang tepat, akan memberikan hasil yang optimal bagi pemahaman peserta didik terhadap materi yang sedang dipelajarinya. Media pembelajaran dapat mempertinggi proses belajar peserta didik sehingga dapat meningkatkan hasil belajar yang dicapai (Ali, 2009). Penggunaan media yang tepat dapat mengatasi sikap pasif peserta didik selama proses belajar mengajar berlangsung (Azhar, 2017).

Salah satu teknologi dalam bidang komputer yang memiliki kemampuan untuk menjadikan media pembelajaran menjadi lengkap adalah teknologi multimedia. Multimedia merangkum berbagai media dalam satu wadah, sehingga memudahkan penyampaian bahan pembelajaran dan pengguna dapat terlibat dalam proses pembelajaran karena teknologi multimedia mempunyai interaktifitas (Kadaruddin. 2018). Peran multimedia sebagai bagian dari media pembelajaran tidak dibatasi pada bidang ilmu apapun. Banyak kelompok maupun lembaga pengembang media pembelajaran yang mengembangkan aplikasi pendidikan berbasis multimedia dari berbagai multi disiplin ilmu, tidak terkecuali pada pelajaran Agama Islam. Kelebihan Media pembelajaran Berbasis Multimedia Multimedia antara lain, a) menyediakan proses interaktif dan memberikan kemudahan umpan balik, b) mudah dianlisis topic proses pembeljarannya, c) memberi kebebasan bagi pelajar (Musfikon, 2012). Salah satu media pebelajaran agama islam yang banyak dikembangkan adalah media pembelajaran untuk pelajaran huruf hijaiyah. Huruf Hijaiyah Berbasis Multimedia merupakan aplikasi interaktif baca tulis huruf hijaiyah untuk pemula yang mengenalkan semua hal yang berhubungan dengan huruf hijaiyah (huruf arab) yang dilengkapi juga dengan Makhraj dan Sifatul Huruf. Aplikasi ini dilengkapi dengan suara/audio untuk setiap bagiannya. Terdapat tanda baca seperti fathah, kasrah, sukun, dhommah, fahtahtain, kasrahtain, dhommahtain dan tasyid. Dalam alikasi pembelajan huruf hijaiyah terdapat aturan mengenai tempat keluarnya huruf-huruf hijaiyah yaitu disebut dengan makhraj.dan aturan tentang penulisan huruf-huruf hijaiyah.Terdapat 29 huruf Hijaiyah yang masing-masing tersebar dalam 30 juz dan 114 surat di dalam Al-Quran. 
Menurut Muazam (2016) kemampuan membaca al-Quran adalah aktivitas kompleks yang mencakup fisik dan mental untuk digunakan melihat tulisan dan mengerti serta dapat melisankan apa yang tertulis di dalam al-Quran. Kemampuan baca al-quran ditinjau dari beberapa indikator, antara lain:

a) Kemampuan membaca dengan makhraj

Secara bahasa, makhraj adalah@ الْرُوُج موَضْع (tempat keluar), sedangkan menurut istilah, makhraj adalah: "Suatu nama tempat, yang pada tempat tersebut huruf dibentuk atau diucapkan"

b) Kemampuan membaca dengan Harakat

Harakat (Arab: حركات, dibaca harakaat).Harakat digunakan untuk mempermudah caramelapazkan huruf dalam tiap ayat al Quran bagi seseorang yang baru belajar dan memahami atau mengenal tanda baca dalam membaca dan melapazkan al Quran.

Kosep kemampuan baca al-quran berdasarkan teori diatas tidak sesuai dengan kondisi masyaraakt yang ada di Desa Tembalae Kabupaten Dompu khusunya pada lansia di daerah tersebut. Hasil pengamatan yang dilakukan peneliti bahwa secara individu terlihat kendala bagi lansia di Kabupaten Dompu untuk mengenal huruf hijaiyah serta pengucapannya yang tidak fasih, sehingga huruf huruf yang hamper sama bunyinya seringkali dibaca sama. Aplikasi belajar AlQur'an berbasis budaya lokal bahasa bima yang telah dikembangkan merupakan system multimedia pembelajaran iqro yang dilengkapi dengan text, suara, gambar, animasi sehingga memudahkan dalam memahami huruf hijaiyah khusunya lansia yang baru belajar membaca Al-Qur an. Deskripsi Conten yang akan disajikan dalam aplikasi belajar Al-Qur'an yang dikembangkan antara lain pembelajaran mengenal angka arab, pengenalan huruf hijaiyah, pembelajaran iqro mulai Fitur dari materi iqro 1 sampai materi iqro 6 dengan contoh bacaannya serta latihannya, informasi referensi buku dan petunjuk penggunaan aplikasi suara, contoh pembacaan, gambargambar, animasi-animasi dan interaktifitas Tombol mulai, keluar, halaman berikutnya, kembali, dan tombol play.

Sebagai upaya mengatasi kesenjangan masalah di atas, peneliti telah mengembangkan media pembelajaran baca Al-quran yaitu Aplikasi Hijaiyah Berbasis Budaya Lokal "Nggahi Mbojo" (Bahasa Bima) yang diperuntukan pada warga lanjut usia (lansia) di Kabupaten Dompu. Aplikasi yang dikembangkan ini digunakan sebagai media pembelajaran oleh peserta didik yang kurang kemampuannya dalam mengenal huruf Hijaiyah. Sisi menariknya dari aplikasi yang telah dikembangkan adalah bahwa setiap huruf Hijaiyah yang ditampilkan dalam aplikasi diartikan dengan bahasa daerah (bahas Bima).

Aplikasi belajar Al-Qur'an berbasis budaya lokal bahasa bima yang telah dikembangkan merupakan system multimedia pembelajaran iqro yang dilengkapi dengan text, suara, gambar, animasi sehingga memudahkan dalam memahami huruf hijaiyah khusunya lansia yang baru belajar membaca Al-Qur an. Deskripsi Conten yang akan disajikan dalam aplikasi belajar Al-Qur'an yang dikembangkan antara lain pembelajaran mengenal angka arab, pengenalan huruf hijaiyah, pembelajaran iqro mulai Fitur dari materi iqro 1 sampai materi iqro 6 dengan contoh bacaannya serta latihannya, informasi referensi buku dan petunjuk penggunaan aplikasi suara, contoh pembacaan, gambar-gambar, animasi-animasi dan interaktifitas Tombol mulai, keluar, halaman berikutnya, kembali, dan tombol play. Dengan aplikasi ini masyarakat khusus lansia dapat membaca mushaf Al-quran dalam bentuk digital sehingga secara kondisional memudahkan waktu dan tempat untuk meningktakan kemampuan baca Al-quran". 


\section{METODE PENELITIAN}

\section{A. Jenis Penelitian}

Jenis penelitian ini adalah pre-experimental design, yaitu penelitian yang belum merupakan eksperimen sungguh-sungguh karena masih terdapat variabel luar yang ikut berpengaruh terhadap terbentuknya variabel dependen (Sugiyono, 2017). Artinya dengan desain penelitian ini diasumsikan bahwa Aplikasi belajar Al-quran yang dikembangkan bukan semata-mata faktor yang mempengaruhi meningkat atau tidaknya kemampuan baca al-quran peserta didik. Desain penelitian ini menggunakan tipe One-Shoot Case Study (Studi Kasus Satu Tembakan). Dimana dalam desain penelitian ini terdapat suatu kelompok diberi treatment (perlakuan) dan selanjutnya diobservasi hasilnya (treatment menggunakan aplikasi baca Al-qura'an merupakan variabel independen dan hasil kemmapuan baca al-qur'an adalah sebagai variabel dependen). Dalam eksperimen ini subjek disajikan dengan beberapa jenis perlakuan lalu diukur hasilnya. Adapun kerangka tipe One-Shoot Case Study (Sugiyono, 2017) dapat dilihat pada gambar di bawah ini:

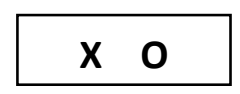

\section{Keterangan:}

$\mathrm{X}=$ perlakuan yang diberikan (penggunaan aplikasi belajar Al-qur'an atau variabel independen)

$\mathrm{O}=$ hasil dari perlakuan (kemampuan baca Al-qur'an atau variable dependen)

\section{B. Populasi Dan Sampel}

\section{Populasi:}

Kakikat dari populasi adalah keseluruhan objek yang diteliti. Populasi merupakan jumlah keseluruhan dari satuan-satuan atau individu-individu yang karakteristiknya hendak diteliti. Dan satuan-satuan tersebut dinamakan unit analisis, dan dapat berupa orang-orang, institusi-institusi, benda-benda, dst. (Sugiyono, 2017). Populasi dari penelitian ini adalah seluruh peserta didik yang tergabung pada "Kelompok Pengajian Lansia Tembalae" Kecamatan Pajo Kabupaten Dompu yang berjumlah 75 orang.

\section{Sampel:}

Menurut Arikunto (2010), Sampel adalah sebagian dari populasi yang dapat dijangkau serta memiliki sifat yang sama dengan populasi yang diambil sampelnya tersebut. Berdasarkan jumlah populasi di atas maka peneliti mengambil sampel sejumlah 25 orang lansia. Teknik Pemilihan sampel secara purposive sampling atau pengambilan sampel berdasarkan tujuan dan karakteristik sampel yang ingin diteliti.

\section{Teknik Pengumpulan Data}

Teknik pengumpulan data yang digunakan pada penelitian ini menggunakan tes. Tes adalah serentetan pertanyaan atau latihan sera alat lain yang digunakan untuk mengukur keterampilan, pengetahuan, kemmapuan atau atau bakat yang dimiliki oleh individu atau kelompok (Arikunto, 2010). Tes yang dimaksud adalah tes kemampuan baca al-quran peserta didik Kelompok Pengajian Lansia Tembalae Kabupaten Dompu setelah menggunakan media pembelajaran aplikasi baca Alqur'an.

\section{Instrumen Penelitian}

Instrumen penelitian adalah suatu alat yang digunakan mengukur fenomena alam maupun sosial yang diamati (Sudjana, 2016). Secara spesifik semua fenomena ini disebut sebagai valriabel penelitian. Variabel penelitan yang diukur dalam penelitian ini yaitu variabel dependen yaitu kemampuan baca Al-qur'an Kelompok Pengajian Lansia Tembalae Kabupaten Dompu yang berjumlah 30 orang. Variabel ini kemudian diukur dengan intrumen sebagai berikut: 
Tabel 1. Kisi-kisi instrumen tes kemampuan membaca al-Qur'an Kelompok Pengajian Lansia Tembalae Kabupaten Dompu

\begin{tabular}{l|l|l|l}
\hline \multicolumn{1}{c|}{ Variabel } & \multicolumn{1}{c|}{ Indikator } & \multicolumn{1}{c}{ Butir Soal } & \multicolumn{1}{c}{ Bobot } \\
\hline Kemapuan baca Al- & $\bullet$ Kelancaran & $\bullet 1$ & Satu soal \\
Qur'an & $\bullet$ Ketepatan Makhra & $\bullet 2,3,4,5,6,7,8$, & memperoleh skor 1 \\
& $\bullet$ Ketepatan Tajwid dan & $\bullet 9,10,11,12$, & \\
& Tanwin & $13,14,15$ & \\
\hline
\end{tabular}

\section{E. Teknik Analisis Data}

Kemampuan Kognitif Lansia (baca dan hafalan Al-Qur'an) Penilaian dari kemampuan kognitif lansia diperoleh dari tes memahami bacaan huruf hijaiyah dan hukum bacaan yang mengacu pada rubrik penilaian serta kemampuan hafalan tata bacaan. Rubrik penilaian dibentuk dalam skala bertingkat yaitu sebuah pernyataan yang diikuti kolom dengan tingkat penskoran skala sesuai dengan kriteria yang ditetapkan, dimana skor 4 jika jawaban lansia sangat benar, dan skor 3 jika jawaban lansia benar, skor 2 jika jawaban lansia cukup benar, skor 1 jika jawaban lansiakurang benar. Untuk mengetahui tingkat kemampuan kognitif lansia, dianalisis secara deskriptif kuantitatif. Untuk mengukur tingkat pencapaian tiap indikator kemampuan berpikir kreatif peserta didik ditentukan dengan rumus sebagai berikut:

\section{AP $=$ jumlah skor yang diperoleh $\times 100 \%$ Jumlah skor maksimal}

Setelah diperoleh hasil persentase kemampuan kognitif lansia, peneliti menentukan kategori kemampuan kognitif lansia. Pemberian kategori bertujuan untuk mengetahui kemampuan kognitif lansia. Kemampuan kognitif lansia dibendakan menjadi 4 kategori, yaitu:

Tabel 2. Konversi kemampuan Baca Al-Qura'an Peserta Didik (Riduwan, 2010)

\begin{tabular}{ll}
\hline Interval Skor & Kategori \\
\hline $91-100$ & Sangat Baik \\
\hline $76-90$ & Baik \\
\hline $51-75$ & Cukup \\
\hline $26-50$ & Kurang \\
\hline $0-25$ & Sangat Kurang \\
\hline
\end{tabular}

\section{HASIL DAN PEMBAHASAN}

A. Hasil Penelitian

Tabel 3. Persentase Nilai Tes Kemampuan Baca Al-Qura'an

\begin{tabular}{cccc}
\hline PD & NT & PD & NT \\
\hline PD-1 & 95 & PD-16 & 80 \\
\hline PD-2 & 75 & PD-17 & 80 \\
\hline PD-3 & 70 & PD-18 & 80 \\
\hline PD-4 & 80 & PD-19 & 95 \\
\hline PD-5 & 80 & PD-20 & 75 \\
\hline PD-6 & 75 & PD-21 & 70 \\
\hline PD-7 & 75 & PD-22 & 85 \\
\hline PD-8 & 75 & PD-23 & 85 \\
\hline PD-9 & 85 & PD-24 & 90 \\
\hline PD-10 & 85 & PD-25 & 70 \\
\hline
\end{tabular}




\begin{tabular}{cccc}
\hline PD & NT & PD & NT \\
\hline PD-11 & 90 & PD-26 & 70 \\
\hline PD-12 & 80 & PD-27 & 85 \\
\hline PD-13 & 80 & PD-28 & 80 \\
\hline PD-14 & 70 & PD-29 & 80 \\
\hline PD-15 & 85 & PD-30 & 85 \\
\hline & & & Rerata $=80 \%$ \\
\hline
\end{tabular}

Keterangan:

$\mathrm{PD}=$ peserta didik (lansia)

$\mathrm{NT}=$ nilai tes (kemampuan baca Al-Qur'an)

\section{B. Pembahasan}

Data yang ditunjukkan pada Tabel 2 di atas merupakan hasil tes kemampuan baca al-quran Kelompok Pengajian Lansia Tembalae Kabupaten Dompu yang berjumlah 30 orang pada bulan Agustus 2020. Hasil ini dinilai berdasarkan indikator pertanyaan yang dibuat dalam bentuk sola tes dengan jumlah 15 butir soal. Hasil tersebut didapatkan tidak serta merta langsung diberikan soal tes, melainkan sebelumnya telah dilakukan pembinaan dan pelatihan terlebih dahulu mengenai penggunaan aplikasi yang dikembangkan. Latar belakang usia, kesibukan peserta didik serta antisipasi penyebaran virus corona mempengaruhi alokasi dan intensitas pelatihan bimbingan aplikasi hijaiyah yang telah dikembangkan. Dalam menyiasati konsisi di atas peneliti mengatur pola pembelajaran dengan system shift. Dari total peserta didik 30 orang, kemudian peneliti membaginya dalam 5 kelompok belajar dengan 1 kelompok terdiri dari 6 orang peserta didik. Setiap kelompok dijadwalkan mekakukan bimbingan dan pelatihan tatap muka selama 2 kali/pekan dan pelatihan ini berlanjut selama satu bulan penuh.

Proses pelatihan serta bimbingan penggunaan aplikasi huruf hijaiyah berjalan kurang lebih 6 pertemuan tatap muka pada masing-masing kelompok. Pada pertemuan ke tujuh dank e delapan peneliti memberikan tes pada 30 peserta didik yang dibagi menjadi dua kelompok tes. Tes yang dimaksud berupa tes kemampuan baca masing-masing peserta didik setelah memanfaatkan aplikasi huruf hijaiyah sebagai media pembelajaran. Tes dilakukan secara bertahap dengan memberikan kesempatan ke setiap pesera didik menghafal dan melafaskan huruf-huruf yang terkandung pada aplikasi yang diberikan. Kategori ketuntasan belajar al-quran peserta didik dinilai berdasarkan skala ketercapaian dengan indikator sangat baik,bauk,cukup, kurang sampai dengan sangat kurang.

Setelah tes dilakukan, kemudian peneliti menganalisis data hasil tes dan hasil temuannya adalah bahwa perolehan skor rata-rata kemampuan membaca al-Quran 30 orang peserta didik adalah yaitu $80 \%$ berada dalam kategori baik. Jika diukur berdasarkan Frekuensi konversi kemampuan baca al-qura'an peserta didik (Riduwan, 2010), maka hasil tes kemampuan baca alquran peserta didik tidak ada yang kurang maupun sangat kurang. Melainkan capiannya pada kategori cukup dan baik. Yang memeproleh predikat cuku baik terdapat 10 orang peserta didik kemudian 20 orang lainnya meperoleh predikat baik. Hasilini menunjukan bahwa proses pembinaan dan pelatihan baca al-quran sangat efektif untuk kelancaran baca al-quran peserta didik khususnya pada kelompok lansia Tembalae Kabupaten Dompu.

\section{SIMPULAN DAN SARAN}

\section{A. Simpulan}

Berdasarkan hasil temuan analisis data dan pembahasan bahwa dapat disimpulkan penggunaan aplikasi hijaiyah berbasis budaya lokal "Nggahi Mbojo" (Bahasa Bima) sangat efektif 
sebagai penunjang proses pembelajaran kemmapuan baca al-quran pada Lansia Kabupaten Dompu. Hasil ini dibuktikan dengan hasil tes kemmapuan baca al-quran 30orang peserta didik (lansia) memperoleh rerata $80 \%$ dengan kategori baik. Hasil ini didukung juga faktor internal yaitu motivasi dan semangat peserta didik dalam mennggunakan aplikasi yang dikembangkan sebagai media pembelajaran baca al-quran.

\section{B. Saran}

Untuk kelancaran dan kepraktisan penggunaan Aplikasi Hijaiyah Berbasis Budaya Lokal "Nggahi Mbojo" (Bahasa Bima) ini diperlukan penguatan dan pembinaan lebih lanjut mengenai cara dan teknis penggunaannya terkhusus pada peserta didik pemula.

\section{DAFTAR RUJUKAN}

Al-Qaththan, Manna. 2017. Dasar-Dasar Ilmu Al-Qur'an. Jakarta: Ummul Qura.

Arikunto, Suharsimi. 2010. Prosedur Penelitian Suatu Pendekatan Praktik. Yogyakarta: Rineka Cipta.

Azhar, Arsyad,. 2017. Media Pembelajaran-edisi revisi.Bandung:Penerbit Rajawali.

Ibrahim, Muslimin. 2005. Assesmen Berkelanjutan. Surabaya: Unesa University Press.

Kadaruddin. 2018. Media dan Multimedia Pembelajaran. Yogyakarta: Deepublish.

Mohammad Ali dkk. 2009. Ilmu dan Apl '̌kasi Pendidikan. Bandung: Imtima.

Ratumanan \& Lauren. 2011. Evaluasi Hasil Belajar pada Tingkat Satuan Pendidikan Edisi Surabaya. Unesa University Press.

Riduwan, (2010). Skala Pengukuran variabel-variabel penelitian. Bandung: Alfabeta.

Sudjana, Nana. 2016. Penilaian Hasil Proses Belajar Mengajar. Bandung: PT Remaja Rosdakarya.

Sugiyono. (2017). Metode Penelitian Kuantitatif, Kualitatif, dan R\&D. Bandung : Alfabeta, CV.

Abu Muazzam, Aplikasi Interaktif Hijaiyah Plus untuk Pemula, http://pustakaabumuazzam. blogspot.co.id/2014/05/aplikasi-interaktif-hijaiyah-plus.html, diakses 7 November 2016).

Musfiqon. 2012. Pengembangan Media dan Sumber Pembelajaran, Jakarta: Prestasi Pustaka. 